Grant, V. 1950. The protection of the ovules in flowering plants. Evolution 4: 179-201.

Hjelmqvist, H. 1948. Studies on the floral morphology and phylogeny of the Amentiferae. Bot. Not., Suppl. 2 : 1-171.

Kuijt, J. 1969. The Biology of Parasitic Flowering Plants. Berkeley: Univ. Calif. Press, 246 pp.

Melchior, H. (ed.) 1964. A. Engler's Syllabus der Pflanzenfamilien. 12th Ed. Vol. 2. Angiospermen. Berlin: Borntraeger. $666 \mathrm{pp}$.

Metcalfe, C. R. \& L. Chalk 1950. Anatomy of the Dicotyledons: Leaves, Stem, and Wood in Relation to Taxonomy, with Notes on Economic Uses. 2 vols. Oxford: Clarendon Press.

Moseley, M. F., Jr. \& R. M. Beeks 1955. Studies of the Garryaceae-I. The comparative morphology and phylogeny. Phytomorphology 5: 314-346.

Raven, P. H. 1974. Cytology and the bases of angiosperm phylogeny. Brittonia (in press).

Stebbins, G. L., Jr. 1951. Natural selection and the differentiation of angiosperm families. Evolution 5: 299-324.

Stern, W. L. 1952. The comparative anatomy of the xylem and the phylogeny of the Julianiaceae. Amer. J. Bot. 39: 220-229.

Stone, D. E. \& C. R. Broome 1971. Pollen ultrastructure: evidence for relationship of the Juglandaceae and the Rhoipteleaceae. Pollen \& Spores 13: 5-14.

Takhtajan, A. 1959. Die Evolution der Angiospermen. Transl. from the Russian by W. Höppner, Berlin. Jena: G. Fischer. 344 pp. 1966. Systema et Phylogenia Magnoliophytorum. Leningrad, Moscow: Komarov Inst. Bot., Acad. Sci. U.S.S.R. 611 pp.

1969. Flowering Plants: Origin and Dispersal. (Transl. from the Russian by C. Jeffrey, Kew.) Edinburgh: Oliver \& Boyd. 310 pp.

Thorne, R. F. 1968. Synopsis of a putatively phylogenetic classification of the flowering plants. Aliso 6(4): $57-66$.

1973. Inclusion of the Apiaceae (Umbelliferae) in the Araliaceae. Notes Roy. Bot. Gard. Edinburgh 32 : 161-165.

Tippo, O. 1940. The comparative anatomy of the secondary xylem and phylogeny of the Eucommiaceae. Amer. J. Bot. 27: 832-838.

Varossieau, W. W. 1942. On the taxonomic position of Eucommia ulmoides Oliv. (Eucommiaceae). Blumea 5: 81-92.

\title{
THE SEVENTH ANNUAL JESSE M. GREENMAN AWARD
}

The seventh Jesse M. Greenman Award will be presented at the 1974 annual banquet of the Botanical Society of America at Tempe, Arizona. This Award of $\$ 200$ is presented each year by the Alumni Association of the Missouri Botanical Garden in recognition of the best paper in plant systematics based on a doctoral dissertation published during the previous year. Papers published during 1973 are now being considered. Reprints of such papers should be sent to Alwyn H. Gentry (Secretary, Alumni Association, Missouri Botanical Garden, 2315 Tower Grove Avenue, St. Louis, Missouri 63110) before May 1, 1974.

William R. Anderson, New York Botanical Garden, is the recipient of the 1973 Award. The winning publication is his "A monograph of the genus Crusea (Rubiaceae)" Mem. New York Bot. Gard. 22(4): 1-128. 1972. 